\title{
Monitoring of Total Suspended Particles \& Toxic Gasses in Stationary Combustion Systems
}

\begin{abstract}
K T Jayasinghe
Abstract: $\quad$ A number of unaccounted combustion systems have been operated island wide to meet various power demands such as electricity generation, product manufacturing, process applications etc. Such systems differ from each other according to the types of combustion, types of fuel used, capacity etc. Whether the processing plant/system is small or large, it requires to burn different kinds of fuels to obtain driving forces. Widely used fuels in the country for these types of combustion systems are coal, heavy oil, light oil, LP gas, fire wood, bagas, bio gas etc.

All combustion systems emit solid waste (e.g. Ash, Charcoal etc.), gaseous waste (e.g. Suspended particles, Carbon Monoxide, Carbon Dioxide, Sulphur Dioxide, Nitrogen Dioxide etc) and waste heat (conduction, convection, radiation etc) as by products during the fuel combustion. Monitoring of such gaseous waste is more difficult than monitoring of solid wastes and waste heat.

There are standard flue gas emission control systems inbuilt with large capacity combustion systems such as electricity generation plants, paper/ sugar industries etc. Also, standard monitoring levels are published by reputed organizations and authorities. However, when renewing the license for setting up a new plant, especially in the Small \& Medium Industries (SMI) it is essential to prove that their combustion systems are operated under the standard level (i.e. environmental friendly manner). But most of the owners ; especially SMI holders, have met with difficulties to get the required environmental certificates due to lack of awareness, non availability of measuring facilities / control mechanisms of old (existing) combustion systems and non availability of reference standards (for small combustion systems) etc.
\end{abstract}

Therefore, this paper aims to discuss the widely used combustion systems in small \& medium industries, common flue gas emission parameters, proposed and applicable environmental standards, sample locations and pre facility required for monitoring.

Key Words: Bagas, Bio Gas, Combined Cycle, Distillation, Effluent Gases, Flue Gas, Hydraulic Diameter, Homogeneity, Parboiling, Refinery, Randleman, Suspended Particles, Volatile, Volumetric Flow

\subsection{Introduction:}

Thermal energy requirements of industries have been met by firing different kinds of fuels in different kinds of combustion chambers. The number of systems available in the country cannot be quantified but can be classified/ categorized according to the type of fuel used, type of plant and type of process application.

Many industries, especially located in urban areas and industrial zones, have obtained required thermal energy by firing heavy oil, their light oil or LP gas in different types of firing chambers. In addition to these fossil fuel systems, many numbers of bio mass fuel combustion systems and limited numbers of coal fired systems are available in different locations.
The emission control of solid fuel combustion systems, such as coal, fire wood, bio mass etc., is rather difficult than the emissions of fossil fuel combustion systems. However, due to the increase of imported fuel prices, many industries have converted their fossil fuel combustion system to solid fuel combustion systems.

Eng. K T Jayasinghe, BSc. Eng (Hon), M Eng (Energy Technology), AMIE(Sri Lanka), Principal Research Engineer, Energy \& Environmental Management Centre, National Engineering Research \& Development Centre. 
Therefore, during the last five years, use of bio mass in industries have been increased to over 681,000 Metric Tons [Annual Energy Balance 2007; Sri Lanka Sustainable Energy Authority].

While increasing the number of firing systems, there would be a high amount of emissions (both particles and gasses) to the atmosphere and therefore, responsible authorities have tightened the environmental rules \& regulations against the industries.

\subsection{Widely Used Combustion Systems in Industries}

The various types of combustion systems available in the country can be categorized into three different groups such as large scale combustion systems, medium scale combustion systems and small scale combustion systems.

The large scale combustion systems comprise up-and-coming new combined cycle power plants, diesel engine power plants, petroleum refineries, bagas combustion systems in sugar mills, kiln and furnaces operated in glass, cement, ceramic industries etc.

Many numbers of furnace oil/ diesel/ fire wood combustion steam or hot water generated boiler systems have been operated in many industries all over the country. These types of combustion systems can be included in the medium scale category. In addition to those boiler systems, different types of kilns, furnaces, dryers, solid waste disposal systems have been used in industries such as garment, food processing, manufacturing, distillation processes, hotel etc.

The small scale processing plants have been widely spread all over the country in urban and rural areas as well. Parboiling systems in rice mills, foundry furnaces, bakeries, charcoal processing, etc can be included in this category.

In addition to the combustion systems, some processing industries emit different kinds of gases and suspended particles to the atmosphere as a waste/or by product from their processing plants, such as chemical processing plants, coir industry, metal crushers, service stations, saw mills etc.

\subsection{Compositions of Exhaust Gases in Combustion Systems}

The main stack emissions from fossil fuel combustion systems are Carbon Dioxide $\left(\mathrm{CO}_{2}\right)$, Carbon Monoxide (CO), Sulphur Dioxide $\left(\mathrm{SO}_{2}\right)$, Oxides of Nitrogen $\left(\mathrm{NO}_{\mathrm{x}}\right)$ and Total Suspended Particles (TSP) or Volatile Organic Compounds (VOC). In addition to these major emission parameters, Lead $(\mathrm{Pb})$, Chlorine $\left(\mathrm{Cl}_{2}\right)$, Methane $\left(\mathrm{CH}_{4}\right)$ etc. are included as minor components and emission of these gases depends on the composition of the fuel.

The emissions of Carbon Dioxide $\left(\mathrm{CO}_{2}\right)$ and VOC in fire wood combustion systems are relatively higher than the emissions of fossil fuel combustion systems. However, $\mathrm{SO}_{2}$ content in fire wood combustion systems is comparatively negligible.

The same pollutants are produced when fuels are burnt elsewhere in any type of application. However, the emission quantity depends on the plant capacity and the operating period.

Flue gas emission parameters in different capacity combustion systems are given in Table-1.

The values given in this table are average figures of several tests in similar kinds of plant/machineries or processes. The values of gases vary within the range of $+/-10 \%$ (except CO level), and the values of TSP vary within the range of $+/-1.0 \%$.

\subsection{Measuring Techniques}

There is a wide choice of different sampling and analytical techniques, published methods and equipment that can be used to carry out stack emission measurements. This paper describes only the widely used and applicable principles, standards, measuring techniques etc. by focusing on the small and medium industries in order to get a general overview to prepare sampling accesses for flue gas analysis. 
Table 1 - Flue Gas Emission Parameters in Different Capacity of Combustion Systems

\begin{tabular}{|c|c|c|c|c|c|c|c|c|c|}
\hline \multirow[b]{2}{*}{ Plant Category } & \multirow[b]{2}{*}{ Fuel Type } & \multicolumn{8}{|c|}{ Parameters } \\
\hline & & $\begin{array}{l}\mathrm{CO}_{2} \\
(\%)\end{array}$ & $\begin{array}{l}\mathrm{CO} \\
(\%)\end{array}$ & $\begin{array}{l}\mathrm{NO}_{\mathrm{x}} \\
(\mathrm{ppm})\end{array}$ & $\begin{array}{c}\mathrm{SO}_{2} \\
(\mathrm{ppm})\end{array}$ & $\mathrm{O}_{2}(\%)$ & $\begin{array}{l}\text { Ex. Air } \\
(\%)\end{array}$ & $\begin{array}{c}\text { Temp. } \\
\left({ }^{\circ} \mathrm{C}\right)\end{array}$ & $\underset{\left(\mathrm{mg} / \mathrm{Nm}^{3}\right)}{\mathrm{TSP}}$ \\
\hline $\begin{array}{l}\text { High Capacity ( } 300 \mathrm{MW}) \\
\text { Electricity Generation }\end{array}$ & Fossil Fuel & 4.5 & 0.002 & 180 & 15 & 15 & 300 & 500 & $80-100$ \\
\hline $\begin{array}{l}\text { High Capacity Thermal \& } \\
\text { Electricity Generation }\end{array}$ & Bagas & 10 & 1.000 & 70 & 650 & 10.0 & 55 & 230 & $\begin{array}{c}3500- \\
4500\end{array}$ \\
\hline $\begin{array}{l}\text { Medium Capacity } \\
(17 \mathrm{MW}) \text { Electricity } \\
\text { Generation }\end{array}$ & Diesel & 5.5 & 0.002 & 775 & 100 & 14 & 250 & 370 & $30-50$ \\
\hline $\begin{array}{l}\text { Medium Capacity Steam } \\
\text { Generation }\end{array}$ & Fossil Fuel & 12 & 0.002 & 30 & 420 & 4 & 25 & 185 & $10-15$ \\
\hline $\begin{array}{l}\text { Medium Capacity Steam } \\
\text { Generation }\end{array}$ & Fire wood & 4 & 0.040 & 50 & 35 & 17 & 400 & 200 & $60-75$ \\
\hline Small Capacity Kiln & $\begin{array}{c}\text { Fossil Fuel } \\
\text { (LP Gas) }\end{array}$ & 3 & 0.001 & 10 & 5 & 17 & 400 & 250 & -- \\
\hline Small Capacity Air Heaters & Fire wood & 3 & 1.500 & 25 & 10 & 15 & 450 & 150 & --- \\
\hline $\begin{array}{l}\text { Incinerator (with } \\
\text { Monitoring System) }\end{array}$ & $\begin{array}{c}\text { Fossil Fuel } \\
\text { / Wastes }\end{array}$ & 9.0 & 0.003 & 45 & 4700 & 6.5 & 45 & 570 & --- \\
\hline $\begin{array}{l}\text { Incinerator (without } \\
\text { Monitoring System) }\end{array}$ & $\begin{array}{c}\text { Fossil Fuel } \\
\text { / Wastes }\end{array}$ & 5 & 0.030 & 130 & 5 & 14 & 200 & 60 & $250-500$ \\
\hline
\end{tabular}

In general, two methods of gas determinations; extractive sampling method and non - extractive sampling method, have been practiced. However, the extractive sampling method is the most common and widely used. In extractive sampling, effluent gases are conditioned to remove interfering substances and particulate matter before being conveyed to the instrument. On the other hand, non extractive sampling does not remove interfering substances and sampling is confined to the gas stream in the stack or duct.

There are two measuring principles in practice to monitor flue gas emissions. These are the Periodic Emission Monitoring (PEM) and Continuous Emission Monitoring (CEM) systems. The PEM is applied to the medium and domestic level combustion systems and the CEM is applied to the large scale combustion systems. In other words, large scale combustion systems have their own inbuilt flue gas monitoring systems. However, the others have to get their consultancies by reputed parties for the measurements.

\subsection{Methods and Standard Codes: Practices}

Many standard methods and codes developed by various standard institutes can be applied to prepare the sample locations and to monitor the emission levels (measurements). However, the parties who are involved in such type of activities should follow the correct and convenient methods. The selection of particular methods/or codes may depend on the type of combustion systems, plant size, fuel used etc. The applicable common methods and standard codes for different combustion systems are given in Table A-1 in Appendix A. Sometimes the relevant standard methods and codes for the particular plant will be provided by the plant manufacture.

\subsection{Local Standards and Parameters Limitations}

The local standards available in the country are still in draft level. These local proposed standards will be implemented by the Central Environmental Authority (CEA) in Sri Lanka. The measuring parameters and limitations of the CEA proposed standards depend on the source specified, type of industries, capacity of the combustion system, method of combustion etc. In addition to those special categorizations, general atmospheric emission standards have been introduced; highlighting the upper limit of emission parameters for any general Stationary Source. Table A-2 in Appendix A shows the general atmospheric emission standards for stationary sources. 


\subsection{Sample Locations and Facility Requirements}

The fundamental principle behind any sampling activity is that a small amount of collected material should be a representative of all the material being monitored. The number of samples (Tests) will depend on the homogeneity of the gas stream. Variations in concentration, temperature or velocity across the duct caused by moisture, gas leakage or air infiltration can effect the measurements.

The sampling approach, techniques, method and equipment that are used can have different effects on the requirements for access, facility and services. However, the following basic requirements should be met with each system.

- access to the sampling point,

- entry for sampling equipment into the stack,

- adequate space to the instruments and personnel,

- $\quad$ provision of essential services, electricity etc

\subsection{Preparations of Sample Locations}

\subsubsection{Position of the Sample Plane}

The selected sampling plane is usually in a section of the duct with five hydraulic diameters of straight duct upstream and two hydraulic diameters downstream. If the sampling planes are to be located near the top of the stack outlet, then the top should be five hydraulic diameters. The sample plane should be situated in a length of straight duct (prefer vertical) with uniform shape and cross sectional area. The sampling point should be as far as possible downstream and upstream avoiding any disturbances such as bends, branches, obstructions, fans, dampers and leaks etc.

[Hydraulic Diameter $=4 x$ Area of Sampling Plane/ Length of Sampling lane Perimeter]

\subsubsection{Number of Sampling Points}

The number of sampling points required is determined by the size of the stack. The minimum number of sample points and sample lines for rectangular and circular ducts are shown in Table 2.
Table 2 - Minimum Number of Sample Points and Sample Lines (ISO 9096:2003)

\begin{tabular}{|c|c|c|c|c|c|}
\hline \multirow[b]{2}{*}{$\begin{array}{c}\text { Range of } \\
\text { Sampling } \\
\text { Plane } \\
\text { Area } \\
\left(\mathrm{m}^{2}\right)\end{array}$} & \multicolumn{3}{|c|}{ Circular Stack } & \multicolumn{2}{|c|}{$\begin{array}{l}\text { Rectangular } \\
\text { Stacks }\end{array}$} \\
\hline & $\begin{array}{c}\text { Range } \\
\text { of Duct } \\
\text { Diameter } \\
\text { (m) }\end{array}$ & \begin{tabular}{|c|} 
Minim $^{\mathrm{m}}$ \\
Number \\
of \\
Sampling \\
Lines \\
(dia.)
\end{tabular} & \begin{tabular}{|c} 
Mini $^{\mathrm{m}}$ \\
Number \\
of \\
Sampling \\
Points pe \\
Plane
\end{tabular} & $\begin{array}{c}\text { Minim }^{\mathrm{m}} \\
\text { Number } \\
\text { of } \\
\text { Side } \\
\text { Divisions }\end{array}$ & \begin{tabular}{|c|}
$\begin{array}{c}\text { Number } \\
\text { of }\end{array}$ \\
Sampling \\
Points \\
per \\
Plane
\end{tabular} \\
\hline$<0.1$ & $<0.35$ & - & 1 & - & 1 \\
\hline $\begin{array}{l}0.1 \text { to } \\
1.0\end{array}$ & $\begin{array}{c}0.35 \text { to } \\
1.1\end{array}$ & 2 & 4 & 2 & 4 \\
\hline $\begin{array}{l}1.1 \text { to } \\
2.0\end{array}$ & $\begin{array}{c}1.1 \text { to } \\
1.6\end{array}$ & 2 & 8 & 3 & 9 \\
\hline$>2.0$ & $>1.6$ & 2 & 12 & $>=3$ & 12 \\
\hline
\end{tabular}

[Source; Environmental Agency - Technical

Guidance - M 1]

\subsubsection{Positions of Sampling Points Along the Sampling Plane}

The sample plane is divided into equal areas (sample lines) and sampling is carried out from points (sample points) in the centre of these areas. There are different standard dimensions for sample points along the sample planes of circular, rectangular and square ducts. The details are not included in this paper, because these are very common and have been practiced while measuring the flow velocity and pressure inside the ducting system. In addition to those requirements, surveying the proposed sampling plane, preliminary velocity survey, and unacceptable characteristics should be considered while selecting the sampling points.

\subsubsection{Sampling Access Port}

The access port shall be big enough for the insertion and removal of the equipment (probes) used and to allow the sampling point to be reached. As per BS EN 13284 - 1; 2002, the access ports should have a minimum diameter of $125 \mathrm{~mm}$ or a surface area of $100 \mathrm{~mm} \times 250 \mathrm{~mm}$ except stacks smaller than $0.7 \mathrm{~m}$ diameter. A smaller socket (say $50 \mathrm{~mm}$ ) may be allowed for the smaller stacks less than $0.7 \mathrm{~m}$ diameter. The port socket shall not project into the gas stream. Typical arrangement of access ports and fitments are shown in Figures 1 to Figure 3. 


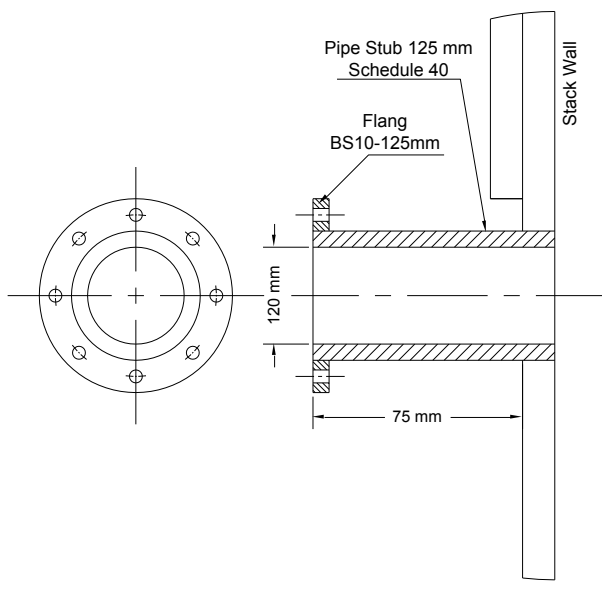

Figure 1 - Standard $125 \mathrm{~mm}$ Access Port [Source - Technical Guide Note M 1]

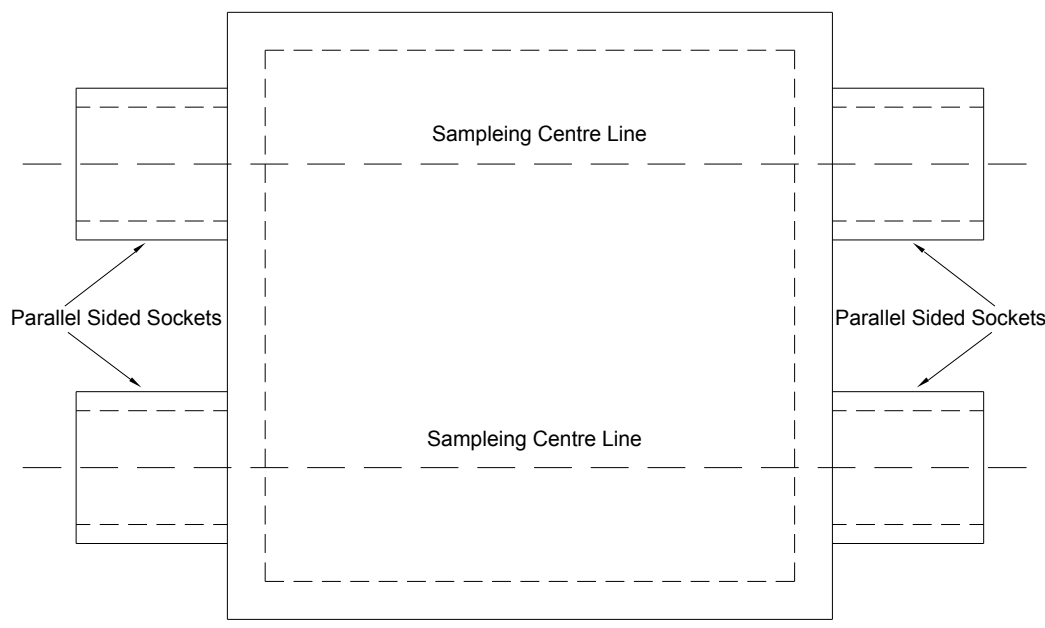

Figure 2 - Plan View of Typical Arrangement of Access Fittings on Large Square Rectangular Stacks [Source - Technical Guide Note M 1]

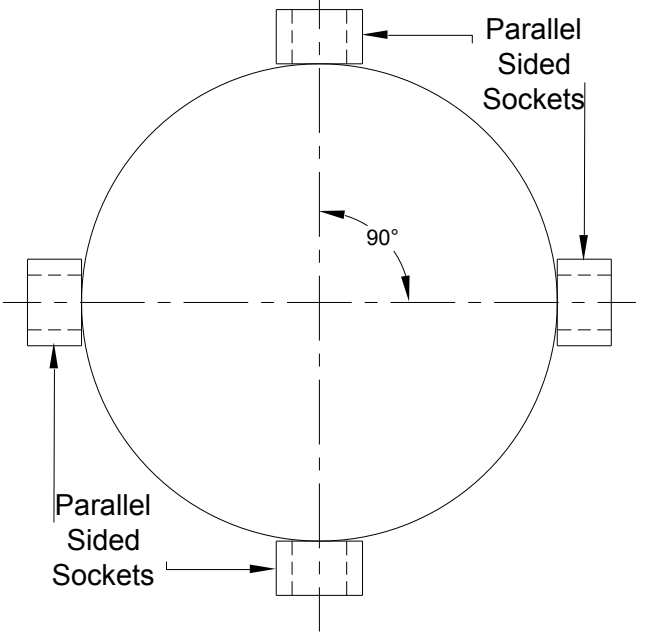

Figure 3 - Plan View of Typical Arrangement of Access Fittings on Large Circular Stacks $(>=3.6 \mathrm{~m}$ Diameter) [Source - Technical Guide Note M 1$]$

\subsection{Sampling Facilities and Safety Requirements}

The safe and permanent working platform and lifting arrangement should be required to reach the sampling locations and the conditions of devices should be confirmed by the responsible parties. However, in exceptional circumstances; such as in old plants or those who cannot bear the setting up facility cost (especially the small scale industries), temporary structures; such as scaffolding can be used. All the platforms, whether permanent or temporary, should meet the weight criteria required for sampling and this is defined as $400 \mathrm{~kg}$ point load as per BS EN 13284- 1:2002 standards. AAs per the Indian Standards the total load should be equivalent to the weight of at least 3 men (average weight $80 \mathrm{~kg}$ each) plus $90 \mathrm{~kg}$ of equipment weight]. The temporary platform should be tied to or supported by a permanent structure. Sampling from roof tops and mobile devices are unacceptable. The platform should provide handrails and kick-boards that meet the requirements of the work place. Removable chains or self closing gates shall be used at the platform to prevent workers falling through access openings or ladders. The platform shall not be accommodated on free standing water and drainage is to be provided [BS EN 13284- 1:2002]. At the top of the platform, $15 \mathrm{Amp}$ and $5 \mathrm{Amp}$, Single phase power supply sockets are required to operate the instruments.

\subsubsection{Space for the Equipment and Personnel}

The space, size requirements and dimensions for platforms are illustrated in Figures 4 to Figure 7.

The platform surface area should not be less than $5 \mathrm{~m}^{2}$ and minimum width at any point shall be 2 $\mathrm{m}$. The minimum length in front of the access port shall be $2 \mathrm{~m}$ or the length of the probe plus $1 \mathrm{~m}$. The platform should be wide enough to prevent sampling equipment extending beyond the platform. 


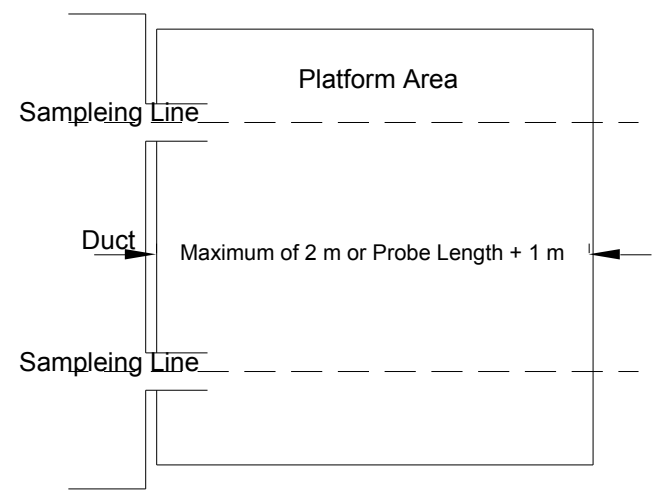

Figure 4 - Typical Area Required E _..... Probe for Handling [Source - Technical Guide Note M 11

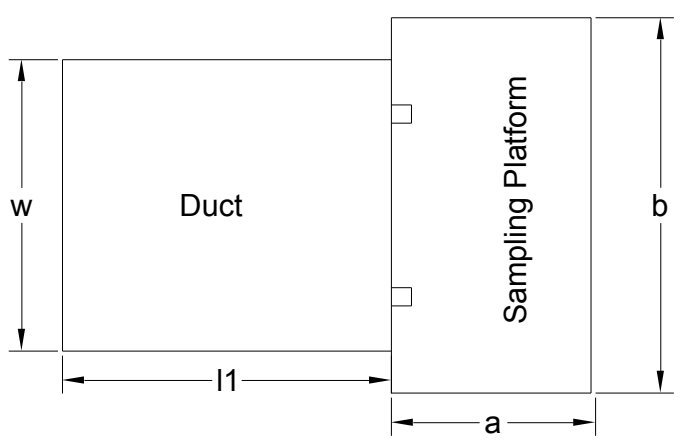

Figure 6 - Plan View of Platform Working Area for Square or Rectangular Ducts (Up to $11=3.6 \mathrm{~m}$ ) [Source - Technical Guide Note M 1]

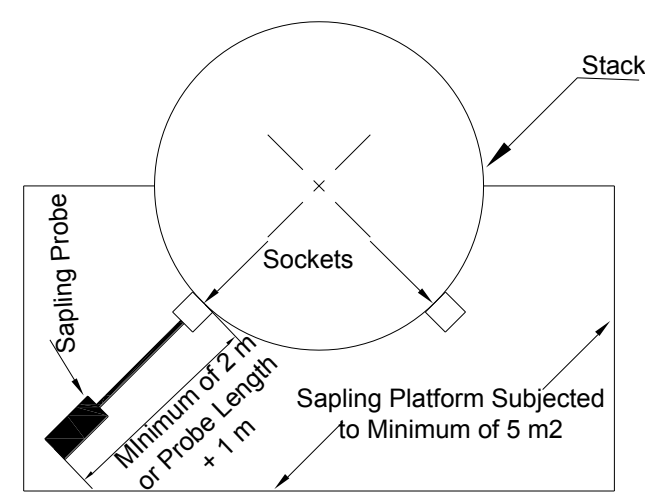

Figure 5 - Plan View of Platform Working Area for Small Vertical Circular Stacks $(<3.6 \mathrm{~m}$ Diameter) [Source - Technical Guide Note M 1]

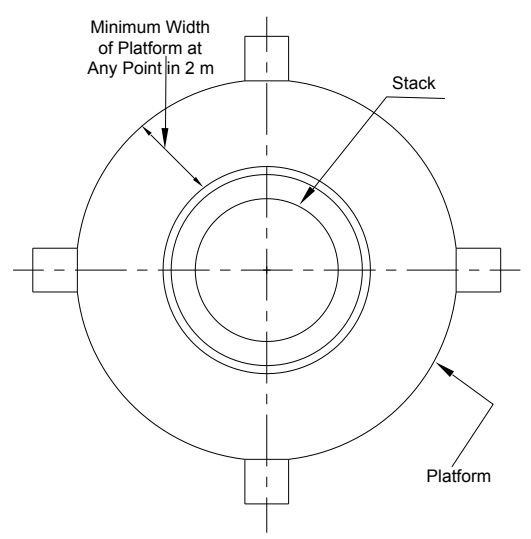

Figure 7 - Plan View of Platform Working Area \& Orientation Recommendations for Large Vertical Circular Stacks (>=3.6 m Diameter) [Source Technical Guide Note M 1]

\begin{tabular}{|l|l|l|l|l|l|l|l|l|l|l|l|l|l|l|l|l|}
\hline Duct Side Length, $\mathrm{l}_{1}(\mathrm{~m})$ & 0.6 & 0.8 & 1.0 & 1.2 & 1.4 & 1.6 & 1.8 & 2.0 & 2.2 & 2.4 & 2.6 & 2.8 & 3.0 & 3.2 & 3.4 & 3.6 \\
\hline Duct Side Width , w $(\mathrm{m})$ & 0.6 & 8.0 & 1.0 & 1.2 & 1.4 & 1.6 & 1.8 & 2.0 & 2.2 & 2.4 & 2.6 & 2.8 & 3.0 & 3.2 & 3.4 & 3.6 \\
\hline Width of Platform, b (m) & 2.0 & 2.0 & 2.0 & 2.0 & 2.0 & 2.0 & 2.1 & 2.2 & 2.3 & 2.4 & 2.5 & 2.6 & 2.7 & 2.8 & 2.9 & 3.0 \\
\hline
\end{tabular}

\subsection{Location Requirements for Monitoring Gases}

The location requirements for measuring gas concentrations are less important than for particulates, as variations in velocity profiles tend not to affect the homogeneity of the gas concentration. This means that the proximity to bends, branches, obstruction fans and dampers are less important. But the sampling after dilution with air must be avoided. However, sometimes it is necessary to measure stack gas velocity and volumetric flow rate. Then the measurements should be taken by following the particulate matter sampling procedures. 


\subsection{Instrumentations}

There are different categories of instruments available to monitor particulates and gas contents in flue gas. The instruments used in different tests may depend on the measuring principles and techniques published by the responsible institutes. However, widely used flue gas analyzing systems and particulate matter monitoring systems are illustrated in Figure 8 \& Figure 9 respectively.

12 Analyser Features

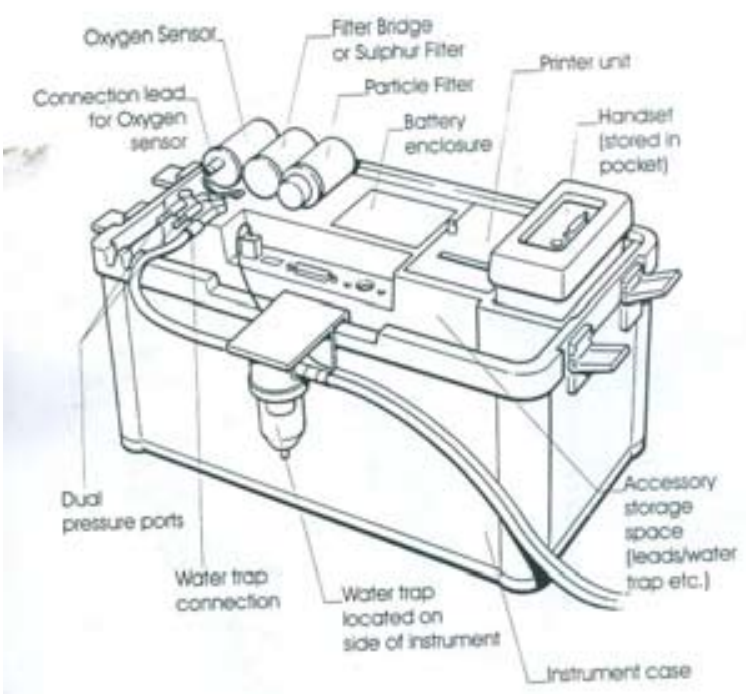

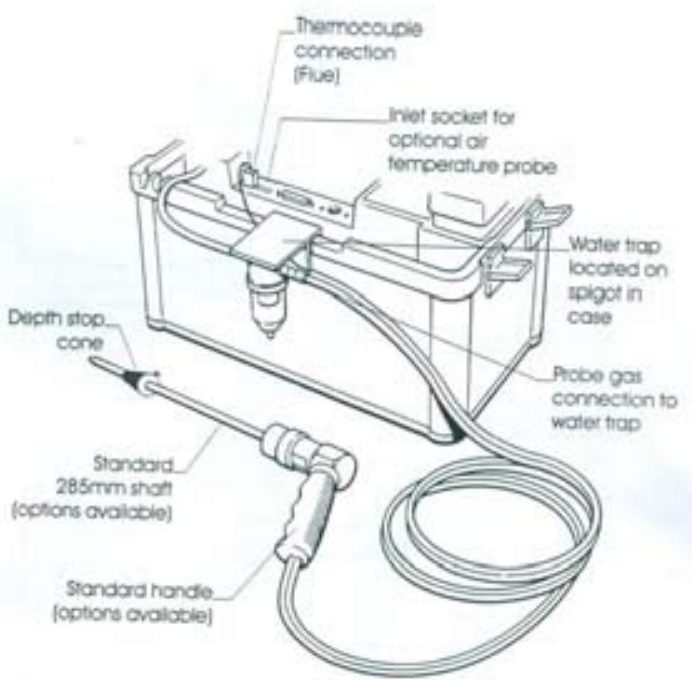

Figure 8 (b)

Figure 8 (a) - Flue Gas Analyzer Feature, Figure 8 (b) - Standard Probe Configurations [Source - KANE International (Pvt.) Ltd., United Kingdom]

Figure 8 (a)

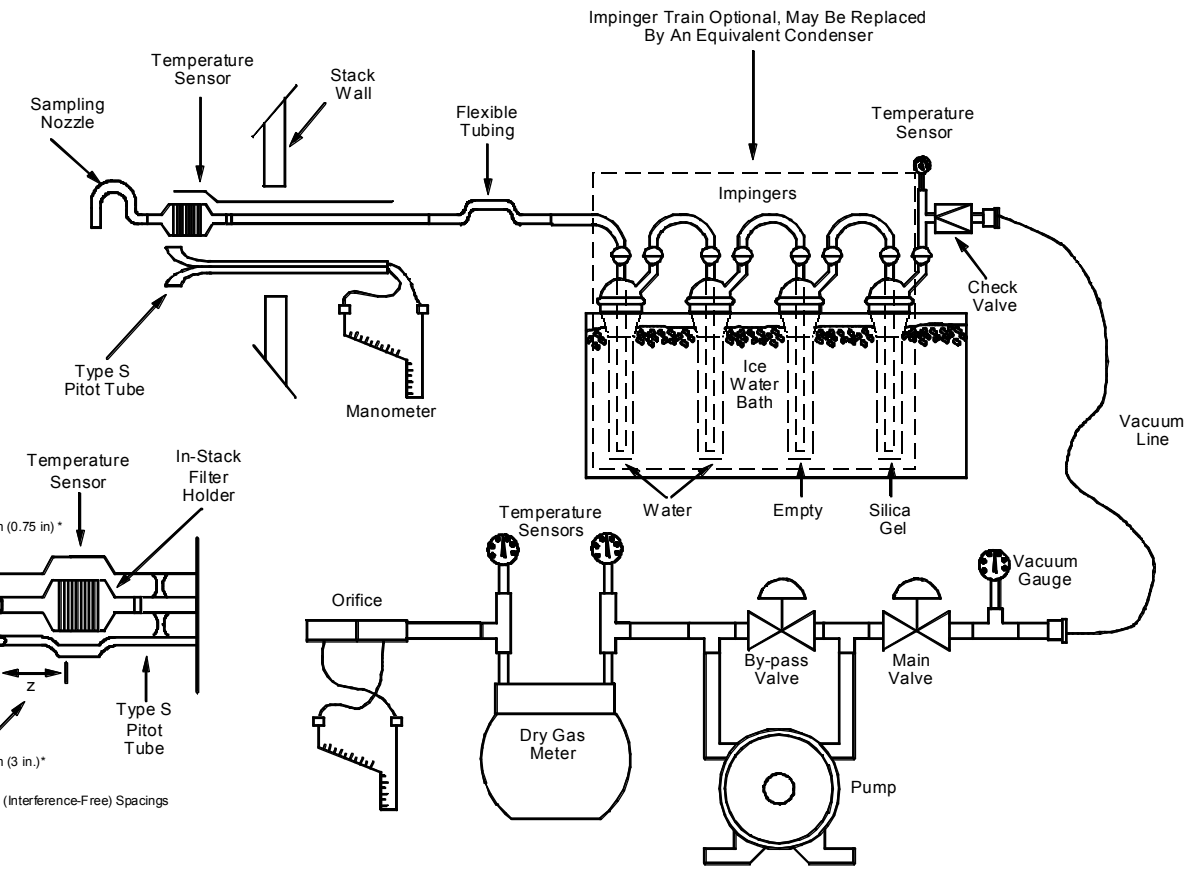

Figure 9 - Particulate Sampling Train, Equipped with In-Stack Filter; [Source - State of California Air Resources Board. 


\subsection{General Recommendations}

6.1 As far as the new environmental rules and regulations, are concerned monitoring of particulate matter and effluent gasses emitted by combustion sources/systems are essential. This monitoring can be either periodical or continuous and the method depends on the definitions of the particular standard.

6.2 Most of the large scale combustion systems have provided the particulate matter and effluent gas controlling mechanisms, such as bag filters, cyclone separators, water spraying etc and the inbuilt effluent gas monitoring system. The sampling ports, working platform and lifting arrangements to reach the sampling locations are also available in those types of combustion systems.

6.3 The combustion system owners (especially SMI owners) who are having old combustion systems (plants without sampling points, lifting arrangement etc) and newcomers to the industries who are going to set up the combustion systems should have considered the instructions and details given in this paper while setting up the effluent gas monitoring system. They should also clearly understand which category of the standard codes have to be followed up with their combustion system.

6.4 More careful attention should be paid to the accurate test results of particulate matter rather than measurements of gaseous concentrations, because nonhomogeneous flow will badly affect the measurements. However, it should avoid the dilution of flue gas with fresh air, while measuring the gaseous concentrations. Further, the toxic gases such as Oxides of Nitrogen should be measured at the pre defined (as per the relevant standards) Oxygen reference level.

\subsection{Acknowledgement}

The author wishes to acknowledge Dr. T B Adikarinayaka; Head of the Department Agriculture and Post Harvest Technology of National Engineering Research \& Development Centre giving his valuable input to standardize this paper.

\section{References}

1. International Standards; ISO 10155 Stationary Source Emissions - Automated Monitoring of Mass Concentrations of Particles - Performance Characteristics, Test Methods and Specifications.

2. International Standards; ISO 7935 Stationary Source Emissions - Determinations of the Mass Concentration of Sulfur Dioxide Performance Characteristics of Automated Measuring Methods.

3. International Standards; ISO 10396 Stationary Source Emissions - Sampling for the Automated Determination of Gas Concentrations.

4. Indian Standard; IS: 11255 (Part 4) - 1985 Methods for Measurements of Emission from Stationary Sources.

5. Technical Guide Note (Monitoring) M 1 Sampling Requirements for Stack Emission Monitoring; Environment Agency, Version 4, July 2006.

6. Technical Guide Note (Monitoring) M 2 Monitoring of Stack Emission to Air; Environment Agency, Version 4, July 2006.

7. $\quad$ Air Quality Sampling Manual; Queensland Government, Environmental Protection Agency

8. Proposed Environmental Standards for Stationary Combustion Sources ; Central Environmental Authority, Sri Lanka

9. “KM 9106" Flue Gas Analyzer Operation Manual, Kane International Limited, Kane House, Swallowfield, Welweyn Garden City, Hertfordshire, AL 7 IJG.

10. “ENVIROTECH APM 621" Stack Monitoring Kit Operation Manual, VAYUBODHAN UPKARAN (Pvt.) Ltd, A 292/1,Okhla Industrial Area, Phase 1, New Delhi - 110020.

11. Environmental Monitoring Reports - Energy $\mathcal{E}$ Environmental Management Centre, National Engineering Research $\mathcal{E}$ Development Centre, 2P/17B, Industrial Estate, Ekala, Ja Ela. Sri Lanka. 


\section{Appendix A}

Table A - 1 - Common Codes and Standards Practice in Monitoring Flue Gas Emission

\begin{tabular}{|c|c|c|}
\hline Name of Standard & Reference Code & Details \\
\hline International Standard & ISO 7935 & $\begin{array}{l}\text { Stationary Source Emission -Determination of } \\
\text { the Mass Concentration of Sulphar Dioxide - } \\
\text { Performance Characteristics of Automated } \\
\text { Measuring Methods }\end{array}$ \\
\hline International Standard & ISO 10155 & $\begin{array}{l}\text { Stationary Source Emission -Automated } \\
\text { Monitoring of Mass Concentrations of Particles - } \\
\text { Performance Characteristics, Test Methods and } \\
\text { Specifications }\end{array}$ \\
\hline International Standard & ISO 10396 & $\begin{array}{l}\text { Stationary Source Emission - Sampling for the } \\
\text { Automated Determination of Gas Concentrations }\end{array}$ \\
\hline Bureau of Indian Standards & IS 11255 (Part 3 \& Part 4) & $\begin{array}{l}\text { Methods for Measurement of Emission from } \\
\text { Stationary Sources }\end{array}$ \\
\hline Environment Agency & Technical Guidance Note - M 1 & $\begin{array}{l}\text { Sampling Requirements for Stack - Emission } \\
\text { Monitoring }\end{array}$ \\
\hline Environment Agency & Technical Guidance Note - M 2 & Monitoring of Stack Emission to Air \\
\hline Environmental Protection Agency & Guidance Note No 1 & Air Emission Sampling Facility \\
\hline $\begin{array}{l}\text { Emission Measurement Technical } \\
\text { Information Centre }\end{array}$ & Method 5 & $\begin{array}{l}\text { Determination of Particulate Emissions from } \\
\text { Stationary Sources }\end{array}$ \\
\hline $\begin{array}{l}\text { Emission Measurement Technical } \\
\text { Information Centre }\end{array}$ & Method 6-A & $\begin{array}{l}\text { Determination of Sulphar Dioxide, Moisture and } \\
\text { Carbon Dioxide from Fossil Fuel Combustion } \\
\text { Sources }\end{array}$ \\
\hline $\begin{array}{l}\text { Emission Measurement Technical } \\
\text { Information Centre }\end{array}$ & Method 6-C & $\begin{array}{l}\text { Determination of Sulphar Dioxide Emission from } \\
\text { Stationary Sources }\end{array}$ \\
\hline $\begin{array}{l}\text { Emission Measurement Technical } \\
\text { Information Centre }\end{array}$ & Method 7 - E & $\begin{array}{l}\text { Determination of Nitrogen Oxides Emission } \\
\text { from Stationary Sources }\end{array}$ \\
\hline $\begin{array}{l}\text { State of California } \\
\text { Air Resources Board }\end{array}$ & Method 17 & $\begin{array}{l}\text { Determination of Particulate Emissions from } \\
\text { Stationary Sources (In-Stack Filtration Method) }\end{array}$ \\
\hline $\begin{array}{l}\text { Central Environmental Authority - Sri } \\
\text { Lanka ; Pollution Control Division }\end{array}$ & Proposed Standards 2.1 & $\begin{array}{l}\text { General Atmospheric Emission Standards for } \\
\text { Stationary Sources }\end{array}$ \\
\hline $\begin{array}{l}\text { Central Environmental Authority - Sri } \\
\text { Lanka ; Pollution Control Division }\end{array}$ & Proposed Standards 2.2 & $\begin{array}{l}\text { Sources Specific Atmospheric Emission } \\
\text { Standards for New Modified Stationary Sources }\end{array}$ \\
\hline
\end{tabular}

Table A-2 - General Atmospheric Emission Standards for Stationary Sources

\begin{tabular}{|c|c|c|c|}
\hline \multicolumn{2}{|c|}{ Name of Substance } & Standard applicable to & Standard \\
\hline \multicolumn{2}{|c|}{ Soot and dust } & Combustion sources & $150 \mathrm{mg} / \mathrm{Nm}^{3}$ \\
\hline \multicolumn{2}{|l|}{ Smoke } & Combustion sources & Ringlemann 2 \\
\hline \multirow{8}{*}{$\begin{array}{l}\text { Harmful } \\
\text { substance }\end{array}$} & $\begin{array}{l}\text { Chlorine }(\mathrm{Cl} 2) \\
\text { Hydrogen chloride }(\mathrm{HCI})\end{array}$ & $\begin{array}{l}\text { Combustion or chemical } \\
\text { treatment at chemical product } \\
\text { reaction facilities or a waste } \\
\text { incinerator }\end{array}$ & $\begin{array}{l}\text { Chlorine: } 30 \mathrm{mg} / \mathrm{Nm}^{3} \\
\text { Hydrogen chloride: } 500 \mathrm{mg} / \mathrm{Nm}^{3}\end{array}$ \\
\hline & $\begin{array}{l}\text { Fluorides }(\mathrm{F}) \\
\text { Hydrogen fluorides }(\mathrm{HF})\end{array}$ & $\begin{array}{l}\text { Any commercial, industrial } \\
\text { processes }\end{array}$ & $\begin{array}{l}\text { Fluoride: } 20 \mathrm{mg} / \mathrm{Nm}^{3} \\
\text { Hydrogen fluorides: } 20 \mathrm{mg} / \mathrm{Nm}^{3}\end{array}$ \\
\hline & $\begin{array}{l}\text { Cadmium }(\mathrm{Cd}) \text { and its } \\
\text { compounds }\end{array}$ & $\begin{array}{l}\text { Combustion or chemical } \\
\text { treatment at a copper, zinc or } \\
\text { lead refinery }\end{array}$ & $10 \mathrm{mg} / \mathrm{Nm}^{3}$ as $\mathrm{Cd}$ \\
\hline & Lead $(\mathrm{Pb})$ and its compounds & $\begin{array}{l}\text { Combustion or chemical } \\
\text { treatment at copper, zinc or } \\
\text { lead refining facilities }\end{array}$ & $10 \mathrm{mg} / \mathrm{Nm}^{3}$ as $\mathrm{Pb}$ \\
\hline & $\begin{array}{l}\text { Antimony (Sb) and its } \\
\text { compound }\end{array}$ & $\begin{array}{l}\text { Any commercial, industrial } \\
\text { processes }\end{array}$ & $10 \mathrm{mg} / \mathrm{Nm}^{3}$ as $\mathrm{Sb}$ \\
\hline & $\begin{array}{l}\text { Arsenic (As) and its } \\
\text { compounds }\end{array}$ & $\begin{array}{l}\text { Any commercial, industrial } \\
\text { processes }\end{array}$ & $20 \mathrm{mg} / \mathrm{Nm}^{3}$ as As \\
\hline & $\begin{array}{l}\text { Copper }(\mathrm{Cu}) \text { and its } \\
\text { compounds }\end{array}$ & $\begin{array}{l}\text { Any commercial, industrial } \\
\text { processes }\end{array}$ & $20 \mathrm{mg} / \mathrm{Nm}^{3}$ as $\mathrm{Cu}$ \\
\hline & $\begin{array}{l}\text { Mercury }(\mathrm{Hg}) \text { and its } \\
\text { compounds }\end{array}$ & $\begin{array}{l}\text { Any commercial, industrial } \\
\text { processes }\end{array}$ & $10 \mathrm{mg} / \mathrm{Nm}^{3}$ as $\mathrm{Hg}$ \\
\hline
\end{tabular}

[Source: CEA Proposed Environmental Standards] 
